\title{
A study of vegetable (thistle) rennet in the production of Flor de Guía cheese
}

\author{
Um estudo sobre o coalho vegetal (cardo) na produção de queijo Flor de Guía
}

\author{
Conrado Carrascosa ${ }^{1}$, Liuva Vega ${ }^{1}$, Rafael Millán ${ }^{1}$, Pedro Saavedra ${ }^{2}$, António Raposo ${ }^{3 *}$, \\ Ariana Saraiva ${ }^{4}$, Esther Sanjuán ${ }^{1}$
}

\begin{abstract}
${ }^{1}$ Department of Animal Pathology and Production, Bromatology and Food Technology, Faculty of Veterinary, Universidad de Las Palmas de Gran Canaria, 35413 Arucas, Las Palmas, Spain; ${ }^{2}$ Department of Mathematics, Universidad de Las Palmas de Gran Canaria, Mathematics Building, Campus Universitario de Tafira, 35018 Las Palmas de Gran Canaria, Spain; ${ }^{3} \mathrm{CBIOS}$ (Research Center for Biosciences and Health Technologies), Universidade Lusófona de Humanidades e Tecnologias, Campo Grande 376, 1749-024 Lisboa, Portugal; ${ }^{4}$ Pharmacy Faculty, University of Coimbra, Azinhaga de Santa Comba, 3000-548 Coimbra, Portugal

*Corresponding author: antonio.raposo@ulusofona.pt
\end{abstract}

\begin{abstract}
The Protected Designation of Origin for Flor de Guía Cheese includes two fundamental requirements: the exclusive use of vegetable (thistle) rennet from Cynara cardunculus var. ferocisisima or Cynara escolymus, as a milk coagulant, and to use certain percentages of milk with respect to the species of origin. These two variables, depending on the random criterion of the cheese-maker, give us the interest of knowing the possible influence they may have on the production process and therefore also on the variability of the final characteristics of the cheese. Thus, the proposed objectives were to study the influence of the use, on the one hand, of different concentrations of thistle $(C$. cardunculus) on the coagulation of different milk types and, on the other, of different mixtures of milk types (of different species) on the coagulation time. The tests for the coagulant activity were carried out following the Berridge technique modified by the NOVO method, obtaining the enzymatic solution from dried thistle flowers in maceration provided by a cheesemaker. The assays showed increased coagulant activity as the concentration of thistle extract increased (especially at low concentrations and on sheep and cow milk) as well as the percentage of sheep milk in the mixtures used as substrate. Further investigations about the use of these two variables, combining high percentages of sheep's milk and thistle extracts of moderate strength, will need for improving the sensory characteristics of Flor de Guía cheese
\end{abstract}

Keywords: Artisanal cheese, Cynara cardunculus, Flor de Guía cheese, vegetable rennet

\begin{abstract}
Resumo
A Denominação de Origem Protegida para o queijo Flor de Guía inclui dois requisitos fundamentais: o uso exclusivo de coalho vegetal (cardo) de Cynara cardunculus var. ferocissima ou Cynara escolymus, como coagulante do leite, e o uso de certas percentagens de leite em relação às espécies de origem. Estas duas variáveis, dependendo do critério aleatório do produtor de queijos, revelam-nos o interesse de conhecer a possível influência que elas podem ter no processo de produção e, portanto, também a variabilidade das características finais do queijo. Assim, os objectivos propostos foram estudar a influência do uso, por um lado, de diferentes concentrações de cardo (C. cardunculus) na coagulação de diferentes tipos de leite e, por outro lado, em diferentes misturas de tipos de leite (de diferentes espécies) no tempo de coagulação. Os testes para a actividade coagulante foram realizados seguindo a técnica de Berridge modificada pelo método NOVO, obtendo a solução enzimática de flores de cardo secas em maceração, fornecidas por um queijeiro. Os ensaios mostraram actividade coagulante aumentada à medida que a concentração de extracto de cardo aumentou (especialmente em baixas concentrações e nos leites de ovelha e vaca), bem como a percentagem de leite de ovelha nas misturas usadas como substrato. Investigações adicionais sobre o uso dessas duas variáveis, combinando altas percentagens de leite de ovelha e extractos de cardo de força moderada, serão necessárias para melhorar as características sensoriais do queijo Flor de Guía.
\end{abstract}

Palavras-chave: Queijo artesanal, Cynara cardunculus, queijo Flor de Guía, coalho vegetal 


\section{Introduction}

The first reference of milk coagulation with thistle, safflower seeds, or fig sap was made 50 years BC. The Greek writer Theophrastus made the first description of the thistle, although its identity was not yet correct. Thistle is cultivated in Europe, where it was introduced approximately in 1685 , and is considered as a culinary speciality as well as a vegetable coagulant. Other plant species (e.g., pineapple, papaya) that also contain enzymes, specifically aspartic proteases, are also capable of coagulating milk. The sap of the wild fig tree has also been described in the Iliad of Homer as a milk coagulant.

Both in Spain and Portugal, extracts of different types of thistle are used for the production of some varieties of sheep cheeses. For the traditional production of these cheeses, the so-called "rennet grass" or "yerbacuajo" from the thistle flowers belonging to different species of the genus Cynara have been used (1).

Cynara cardunculus, commonly known as thistle, is a specie native to the Mediterranean, which belongs to the family Compositae (Asteraceae), grows wild in the south and west of the Mediterranean, Portugal, Madeira and the Canary Islands (2). It is the most popular species and the most used to make different Protected Designation of Origin (PDO) cheeses both in Spain and Portugal, although $C$. humilis and $C$. scolymus are species that are suitable for making these cheeses. They can be used as substitutes or mixed with $C$. cardunculus (3).

The main enzymes of $C$. cardunculus, responsible for coagulation are cardosins A and B, located in the feminine part of the plant. Cardosin $\mathrm{A}$ is considered to have activity and specificity similar to chymosin (an enzyme located in the stomach of ruminants), while cardosin $\mathrm{B}$ is similar to pepsin (also an enzyme located in the stomach of ruminants) (4). Cardosin B has a greater coagulant activity than A and C (5). Nowadays cardosins $\mathrm{A}$ and $\mathrm{B}$ are also known as cyprosins. The milk coagulation activity of this enzyme is due to the presence of three aspartic proteases, initially named cynarases 1,2 and 3 (cyprosin B corresponding to cynarase 3), cardosin $\mathrm{A}$ is also known as cyprosin 1 and 2, while $\mathrm{B}$ as cyprosin 3 (6).

\section{Introdução}

A primeira referência de coagulação do leite com cardo, sementes de açafrão ou seiva de figo foi feita 50 anos A. C. O escritor grego Theophrastus fez a primeira descrição do cardo, embora a sua identidade ainda não estivesse correta. $\mathrm{O}$ cardo é cultivado na Europa, onde foi introduzido aproximadamente em 1685, e é considerado uma especialidade culinária e também um coagulante vegetal. Outras espécies vegetais (por exemplo, ananás, papaia) que também contêm enzimas, especificamente proteases aspárticas, também são capazes de coagular o leite. Além disso, a seiva da figueira selvagem foi descrita na Ilíada de Homero como coagulante do leite.

Tanto em Espanha como em Portugal, extractos de diferentes tipos de cardo são utilizados para a produção de algumas variedades de queijos de ovelha. Para a produção tradicional desses queijos, foi utilizado o chamado "rennet-grass" ou "yerbacuajo" das flores de cardo pertencentes a diferentes espécies do género Cynara (1).

Cynara cardunculus, vulgarmente conhecido como cardo, é uma espécie nativa do Mediterrâneo, pertencente à família Compositae (Asteraceae), que cresce selvagem no sul e oeste do Mediterrâneo, Portugal, Madeira e Ilhas Canárias (2). É a espécie mais popular e a mais usada para fabricar diferentes queijos de Denominação de Origem Protegida (DOP) tanto em Espanha como em Portugal, embora $C$. humilis e $C$. scolymus sejam espécies adequadas para a produção destes queijos. Estas espécies podem ser usados como substitutos ou misturados com C. cardunculus (3).

As principais enzimas de C. cardunculus, responsáveis pela coagulação, são as cardosinas A e B, localizadas na parte feminina da planta. Considera-se que a cardosina A possui actividade e especificidade semelhantes à quimosina (uma enzima localizada no estômago dos ruminantes), enquanto a cardosina $\mathrm{B}$ é semelhante à pepsina (também uma enzima localizada no estômago dos ruminantes) (4). A cardosina B tem uma actividade coagulante maior que A e C (5). Actualmente, as cardosinas A e B também são conhecidas como ciprosinas. A actividade de coagulação do leite desta enzima é devida à presença de três proteases aspárticas, inicialmente denominadas cinarases 1, 2 e 3 (ciprosina B correspondente à cinarase 3 ), cardosina $\mathrm{A}$ também conhecida como ciprosina 1 e 2 , enquanto a B conhecida como ciprosina $3(6)$. 


\section{Cheeses produced with vegetable plant rennet}

In the Iberian Peninsula, especially in the area of Andalucía, Extremadura, Portugal and also the Canary Islands, different types of cheeses are produced with vegetable rennet and they are considered, in turn, PDO cheeses. Cynara cardunculus is the most common species of vegetable rennet that is used to make these cheeses by virtue of the high proteolytic activity of the enzymes located in its pistils.

Next, we describe the main PDO cheeses with their sensory and physical characteristics, from Portugal, Extremadura, Andalucía and the Canary Islands, made with vegetable rennet. Popular cheeses (7) made with vegetable rennet in Portugal include Serpa cheese, Azeitão Cheese, Évora cheese, Serra de Estrella cheese, Nisa cheese, and Castelo Branco cheese. Popular cheeses made with vegetable rennet in Spain include Torta del Casar cheese, La Serena cheese, Añejo de los Pedroches cheese, and Flor de Guía Cheese from the Canary Islands.

\section{Flor de Guía Cheese}

According to the Official State Gazette (BOE) with Resolution of April 15, 2008 for the elaboration of this type of cheese (8), Flor de Guía cheese will have to respect certain percentages of milk: "elaborated fundamentally with milk of Canarian sheep admitting, nevertheless, the mixture of milk of ewe with the one of other species, provided that the following proportions are respected: Canary sheep milk will always be present at least $60 \%$ ". "The maximum percentage to be used for Canarian cow's milk and its crosses will be $40 \%$. The maximum proportion to be used of goat milk of any of the Canarian breeds is set at $10 \%$ ". It is also mentioned that: "Its main characteristic is that the coagulation of the milk will be made exclusively with vegetable rennet obtained from the dried flower heads of the varieties of the varieties of thistle $C$. cardunculus var. ferocissima and C. scolymus" (8).

For this reason, in this study we have set two clear objectives, 1) study the influence of the use of different concentrations of thistle (C. cardunculus) in the coagulation of different types of milk (coagulating activity), and 2) consider the effect on coagulation time through the use of thistle extract from the obtained mixtures of milk different species contemplated in the PDO used as raw material for the production of cheese and therefore, it could be the starting point of future studies about their influence on the final characteristics of the product.

\section{Queijos produzidos com coalho de vegetais}

Na Península Ibérica, especialmente na região da Andaluzia, Extremadura, Portugal e também nas Ilhas Canárias, diferentes tipos de queijos são produzidos com coalho de vegetais, que são considerados, por sua vez, queijos DOP. Cynara cardunculus é a espécie mais comum de coalho vegetal usada para fazer esses queijos em virtude da sua elevada actividade proteolítica das enzimas localizadas em seus pistilos.

Em seguida, descrevemos os principais queijos DOP com as suas características sensoriais e físicas, de Portugal, Extremadura, Andaluzia e Ilhas Canárias, elaborados com coalho de vegetais. Os queijos populares $(6,7)$ elaborados com coalho de vegetais em Portugal incluem queijo de Serpa, queijo de Azeitão, queijo de Évora, queijo Serra da Estrella, queijo de Nisa, e queijo de Castelo Branco. Os queijos populares elaborados com coalho de vegetais em Espanha incluem queijo Torta del Casar, queijo La Serena, queijo Añejo de los Pedroches, e queijo Flor de Guía das Ilhas Canárias.

\section{Queijo Flor de Guía}

De acordo com o Diário Oficial do Estado (BOE) com a Resolução de 15 de abril de 2008 para a elaboração deste tipo de queijo (8), o queijo Flor de Guía deverá respeitar determinadas porcentagens de leite: "elaborado fundamentalmente com leite de ovelha das Canárias, admitindo, no entanto, a mistura de leite de ovelha com a de outras espécies, desde que sejam respeitadas as seguintes proporções: estar sempre presente pelo menos 60\%". "O percentual máximo a ser usado para o leite de vaca das Canárias e seus cruzamentos será de $40 \%$. A proporção máxima a ser utilizada para o leite de cabra de qualquer uma das raças das Canárias é fixada em 10\%". Também é mencionado que: "A sua principal característica é que a coagulação do leite será feita exclusivamente com coalho vegetal obtidos a partir das cabeças secas das flores das variedades de cardo C. cardunculus var. ferocissima e C. scolymus" (8).

Por esse motivo, neste estudo, estabelecemos dois objetivos claros: 1) estudar a influência do uso de diferentes concentrações de cardo (C. cardunculus) na coagulação de diferentes tipos de leite (actividade de coagulação) e 2) considerar a efeito no tempo de coagulação através do uso de extracto de cardo das misturas de leite obtidas de diferentes espécies contempladas na DOP utilizadas como matéria-prima para a produção de queijo e, portanto, poderia ser o ponto de partida de estudos futuros sobre a sua influência nas características finais do produto. 


\section{Materials and Methods}

In this work, we used dried wild thistles of the species C. cardunculus, which were provided by a cheese factory located in Santa María de Guía (Gran Canaria) where they are used for the production of their cheeses. For the preparation of the thistle extract used in this study, we followed the same guidelines as those followed by the cheesemaker (in terms of the water used for maceration, filter purifier, maceration time and temperature). Thus, the coagulation of the milk for the preparation of the cheeses took place in $30-60$ minutes at $37^{\circ} \mathrm{C}$ and $62 \%$ relative humidity.

When the thistles flowers have been harvested and the petals were dried, then they were stored in hermetically sealed bags or crystal containers until being used at the maceration process. The appropriate amount of thistle flower was weighed; distilled water was added, in a controlled amount to allow maceration. This process has been standardized by the PDO Flor de Guía cheese, where the manipulation and concentration of thistle flower (C. cardunculus) are described.

In order to obtain an optimized enzymatic solution, solutions were prepared at five different concentrations. An initial concentration of $0.13 \mathrm{~g}$ of thistle extract in $12.5 \mathrm{ml}$ of distilled water was made, simulating the same concentrations used by the cheesemaker with the same quantity of water. Likewise, duplicate $(0.26 \mathrm{~g})$, triplicate $(0.39 \mathrm{~g})$, quadruplicate $(0.52 \mathrm{~g})$, and quintuplicate $(0.65 \mathrm{~g})$ concentrations were each prepared in $12.5 \mathrm{~mL}$ of distilled water. Tests were carried out with these concentrations to determine which best adapts to the criterion of the Berridge technique modified by the NOVO method (9), which recommends that the best concentration of thistle extract is that which coagulates the milk in $4.5-5.5$ minutes.

\section{Reconstituted milk}

In order to carry out the coagulation time tests for the different extracts prepared with different concentrations of thistle, the Severinsen technique (9) indicates that they must be carried out on reconstituted milk, with specific characteristics.

The reconstituted milk was made using skimmed milk powder (Nestlé Spain S.A., Barcelona, Spain). For its reconstitution, $12 \mathrm{~g}$ of powdered milk was mixed in 100 $\mathrm{ml}$ of $0.01 \mathrm{M} \mathrm{CaCl}_{2}(1873,1000$, Panreac Applicem, Barcelona, Spain).

\section{Materiais e Métodos}

Neste trabalho, utilizámos cardos selvagens secos da espécie C. cardunculus, fornecidos por uma fábrica de queijos localizada em Santa María de Guía (Gran Canaria), onde são utilizados para a produção dos seus queijos. Para a preparação do extracto de cardo, utilizado neste estudo, seguimos as mesmas orientações do fabricante de queijos (em termos de água utilizada para maceração, purificador de filtro, tempo e temperatura de maceração). Quando as flores de cardos são colhidas e as pétalas secas, elas foram armazenadas em sacos hermeticamente fechados ou em recipientes de cristal até serem utilizadas no processo de maceração.

As pétalas secas foram armazenadas em sacos hermeticamente fechados. A quantidade adequada de flor de cardo foi pesada; foi adicionada água destilada, em quantidade controlada para permitir a maceração. Este processo foi padronizado pelo queijo DOP Flor de Guía, onde são descritas a manipulação e a concentração da flor de cardo (C. cardunculus).

Para obter uma solução enzimática optimizada, foram preparadas soluções em cinco concentrações diferentes. Foi realizada uma concentração inicial de $0,13 \mathrm{~g}$ de extracto de cardo em 12,5 ml de água destilada, simulando as mesmas concentrações usadas pelo queijeiro com a mesma quantidade de água. Da mesma forma, as concentrações de duplicado $(0,26 \mathrm{~g})$, triplicado $(0,39 \mathrm{~g})$, quadruplicado $(0,52 \mathrm{~g})$ e quintuplicado $(0,65 \mathrm{~g})$ foram preparadas em 12,5 $\mathrm{ml}$ de água destilada. Foram realizados testes com estas concentrações para determinar a que melhor se adapta ao critério da técnica de Berridge modificado pelo método NOVO (9), que recomenda que a melhor concentração do extracto de cardo seja a que coagula o leite em 4,5-5,5 minutos.

Por fim, a coagulação do leite para a preparação dos queijos ocorreu em $30-60$ minutos a $33-34^{\circ} \mathrm{C}$ e $62 \%$ de humidade relativa.

\section{Leite reconstituído}

Para realizar os testes de tempo de coagulação para os diferentes extractos preparados com diferentes concentrações de cardo, a técnica Severinsen (9) indica que eles devem ser realizados em leite reconstituído, com características específicas.

O leite reconstituído foi elaborado com leite em pó desnatado (Nestlé Spain S.A., Barcelona, Spain). Para sua reconstituição, $12 \mathrm{~g}$ de leite em pó foram misturados em $100 \mathrm{ml} \mathrm{de} \mathrm{CaCl}_{2}$ 0,01 M (1873,1000, Panreac Applicem, Barcelona, Espanha). 
Table 1 - Milk type combinations evaluated. Values shown are relative percentages \%

Tabela 1 - Combinações de tipos de leite avaliadas. Os valores mostrados são percentagens relativas \%

Treatment / Tratamento

\begin{tabular}{lccccccccc}
\cline { 2 - 9 } & $\mathbf{1}$ & $\mathbf{2}$ & $\mathbf{3}$ & $\mathbf{4}$ & $\mathbf{5}$ & $\mathbf{6}$ & $\mathbf{7}$ & $\mathbf{8}$ & $\mathbf{9}$ \\
\hline Sheep/Ovelha & 60 & 60 & 70 & 70 & 80 & 80 & 90 & 90 & 100 \\
\hline Cow/Vaca & 30 & 40 & 20 & 30 & 10 & 20 & 0 & 10 & 0 \\
\hline Goat/Cabra & 10 & 0 & 10 & 0 & 10 & 0 & 10 & 0 & 0 \\
\hline
\end{tabular}

\section{Mixed milk from cow, sheep and goat}

The milk used for the observation of the influence of the percentages of mixed milk from different species (cow, sheep and goat) in the coagulation tests with thistle extract was collected directly from the farm. The milk was obtained after milking the animals, and they were transported (1.5 L of each species), directly to the laboratory of Bromatology of the Faculty of Veterinary of the University of Las Palmas de Gran Canaria, where they were stored at $4^{\circ} \mathrm{C}$ into the refrigerator.

The samples were distributed in quantities of $10 \mathrm{ml}$ in glass test tubes, separated according to milk species and kept frozen until required for further analysis.

Table 1 shows the experimental conditions, which are defined by the percentage that must be higher or equal to $60 \%$ for sheep milk and for cow and goat milks, less than or equal to $40 \%$ and $10 \%$, respectively.

\section{Coagulation test of milk with thistle extract}

The Berridge technique, modified by the NOVO method (9), was used to determine the coagulant force of the thistle rennet produced. Thus, $10 \mathrm{ml}$ of each mixture of milk and reconstituted milk, previously adjusted to $\mathrm{pH}$ 6.4 by the addition of $0.1 \mathrm{~N}$ of $\mathrm{NaOH}$ (181693.1211, Panreac Applicem, Barcelona, Spain), were placed in test tubes and left to be tempered in a bain-marie at approximately $33-34{ }^{\circ} \mathrm{C}$. Next, $1 \mathrm{ml}$ of the solution of the prepared thistle extract was added to each of the test tubes and placed again in a bain-marie in an inclined position.

The tubes were rotated slowly manually (ten times) to observe the moment of the formation of the lumps in the wall of the tube or the breakage of the milk film. The coagulation time from the beginning of inoculation with the extract to the beginning of coagulation was measured. The coagulation tests in the different milk mixtures were done in five replicates.

All coagulation time control tests were performed by the same observer under the same criteria.

\section{Leite misto de vaca, ovelha e cabra}

O leite utilizado para a observação da influência das percentagens de leite misto de diferentes espécies (vaca, ovelha e cabra) nos testes de coagulação com extracto de cardo foi recolhido directamente da quinta. A mistura foi obtida após a ordenha dos animais e estes foram transportados (1,5 1 de cada espécie), directamente para o laboratório de Bromatologia da Faculdade de Veterinária da Universidade de Las Palmas de Gran Canaria, onde foram armazenados a $4^{\circ} \mathrm{C}$ em refrigeração.

As amostras foram distribuídas em quantidades de 10 $\mathrm{ml}$ em tubos de ensaio de vidro, separados de acordo com as espécies de leite e mantidos congelados até serem necessários para análises posteriores.

A Tabela 1 mostra as condições experimentais, definidas pela percentagem, que deve ser maior ou igual a $60 \%$ para o leite de ovelha e para os leites de vaca e cabra, inferior ou igual a $40 \%$ e $10 \%$, respectivamente.

\section{Teste de coagulação do leite com extracto de cardo}

A técnica de Berridge, modificada pelo método NOVO (9), foi utilizada para determinar a força coagulante do coalho produzido pelo cardo. Assim, $10 \mathrm{ml}$ de cada mistura de leite e leite reconstituído, previamente ajustados a pH 6,4 pela adição de $0,1 \mathrm{~N}$ de $\mathrm{NaOH}$ (181693.1211, Panreac Applicem, Barcelona, Espanha), foram colocados em tubos de ensaio e colocados para serem temperados em banho-maria a aproximadamente $33-34{ }^{\circ} \mathrm{C}$. Em seguida, $1 \mathrm{ml}$ da solução do extracto de cardo preparado foi adicionado a cada um dos tubos de ensaio e colocado novamente em banho-maria em posição inclinada.

Os tubos foram rotacionados lentamente manualmente (dez vezes) para observar o momento da formação dos grumos na parede do tubo ou a quebra do filme de leite. Foi medido o tempo de coagulação desde o início da inoculação com o extracto até o início da coagulação. Os testes de coagulação nas diferentes misturas de leite foram realizados em cinco repetições. 


\section{Statistical analysis}

A graphic exploration of the data suggests that the coagulation time (until the beginning) decreased as the percentage of sheep's milk increased, but tends to increase when at a percentage of $100 \%$ (i.e., using sheep's milk only). Therefore, the variables included in the multivariate linear analysis were: \% Sheep, \% Cow and binary variable with value one when $\%$ Sheep $=100$ and zero otherwise $(\%$ Sheep $=100)$.

Then, a selection of variables based on the subset best regression and Bayesian Information Criterion (BIC) was conducted. The estimated model was summarized as coefficients, standard errors (SE,) and p-values. The goodness of fit was assessed by mean of the adjusted $\mathrm{R}$-square, which takes values between 0 and 1. Statistical significance was set at $p<0.05$. Data was analyzed using the R package, version 3.1.1 (10).

\section{Results and Discussion}

\section{Determination of the strength of rennet}

In order to assess the strength of this vegetable rennet (thistle), tests were conducted to coagulate reconstituted milk at $\mathrm{pH} 6.4$ with different concentrations of thistle extract (Table 2), according to the NOVO technique (9). The different experiments obtained are presented below:

According to the Storch and Segelke equation, the reaction speed must be proportional to the concentration of the enzyme and, consequently, the product of the rennet concentration multiplied by the coagulation time of the milk must be constant. That is to say:

\section{$\mathbf{C} \mathbf{x} \mathbf{T}=\mathbf{K}$}

$\mathrm{C}=$ rennet concentration; $\mathrm{T}=$ milk coagulation time $; \mathrm{K}=$ constant.

This occurs in the tests carried out in this study, especially in concentrations of 1 to $3 \%$ of the thistle extract tested. It is necessary to take into account the variability of the enzymatic concentration in each prepared extract, however, it is not possible to control the parts of dried thistle.
Todos os testes de controlo do tempo de coagulação foram realizados pelo mesmo observador, sob os mesmos critérios.

\section{Análise estatística}

Uma exploração gráfica dos dados sugere que o tempo de coagulação (até o início) diminuiu à medida que a percentagem de leite de ovelha aumentou, mas tende a aumentar quando em uma porcentagem de $100 \%$ (ou seja, usando apenas leite de ovelha). Portanto, as variáveis incluídas na análise linear multivariada foram: \% ovelha, \% vaca e variável binária com valor 1 quando $\%$ ovinos $=100$ e zero caso contrário $(\%$ ovinos $=100)$. Em seguida, foi realizada uma selecção de variáveis com base no melhor subconjunto de regressão e no Critério de Informação Bayesiano (BIC). O modelo estimado foi resumido em coeficientes, erros padrão (SE) e valores de p. A qualidade do ajuste foi avaliada por meio do R quadrado ajustado, que assume valores entre 0 e 1 . A significância estatística foi definida como $p$ $<0,05$. Os dados foram analisados através do pacote $R$, versão 3.1.1 (10).

\section{Resultados e Discussão}

\section{Determinação da força do coalho}

Para avaliar a força deste coalho vegetal (cardo), foram realizados testes para coagular o leite reconstituído a pH 6,4 com diferentes concentrações de extracto de cardo (Tabela 2), de acordo com a técnica NOVO (9). As diferentes experiências obtidas são apresentadas abaixo:

Segundo a equação de Storch e Segelke, a velocidade da reação deve ser proporcional à concentração da enzima e, consequentemente, o produto da concentração de coalho multiplicada pelo tempo de coagulação de leite deve ser constante. Ou seja:

\section{$\mathbf{C} \times \mathbf{T}=\mathbf{K}$}

$\mathrm{C}=$ concentração do coalho; $\mathrm{T}=$ tempo de coagulação do leite; $\mathrm{K}=$ constante.

Isto ocorre nos testes realizados neste estudo, principalmente nas concentrações de 1 a $3 \%$ do extracto de cardo testado. É necessário ter em consideração a variabilidade da concentração enzimática em cada extracto preparado, no entanto, não é possível controlar as partes do cardo seco. 
Table 2 - Coagulation times (minutes), depending on the concentration of thistle used

Tabela 2 - Tempos de coagulação (minutos), dependendo da concentração de cardo utilizada

\begin{tabular}{|c|c|c|c|}
\hline \multirow{2}{*}{$\begin{array}{l}\text { Concentration of extract / } \\
\text { Concentração de extracto } \\
\qquad\left(\mathrm{g} / 100 \mathrm{ml} \mathrm{H}_{2} \mathrm{O}\right)\end{array}$} & \multicolumn{3}{|c|}{ Coagulation time / Tempo de coagulação } \\
\hline & $\begin{array}{c}\text { Test / } \\
\text { Teste } 1\end{array}$ & $\begin{array}{c}\text { Test / } \\
\text { Teste } 2\end{array}$ & $\begin{array}{l}\text { Average time / } \\
\text { Tempo médio }\end{array}$ \\
\hline 1 & $19: 46$ & 18:04 & $18: 75$ \\
\hline 2 & $8: 34$ & $9: 14$ & $8: 74$ \\
\hline 3 & 6:08 & $5: 40$ & $5: 74$ \\
\hline 4 & $4: 16$ & $4: 09$ & $4: 125$ \\
\hline 5 & $3: 23$ & $3: 28$ & $3: 255$ \\
\hline
\end{tabular}

As the concentration of thistle extract increased, the coagulation time was shorter. At a concentration of $1 \%$, coagulation was made at 18:75 minutes, while for a concentration of $5 \%$, only $3: 255$ minutes are needed. In general, high concentrations of thistle flower extract do not significantly influence coagulation activity, however, at low concentrations, coagulation time tends to increase with decreasing enzyme concentration (Figure 1).

These observations were in agreement with those carried out by Garcia et al. $(11,12)$ in a study that compared the use of two types of thistle extract (Cynara cardunculus L. and Cynara scolymus L.) on the coagulation time of milk. A similar result was observed by Sanjuán and Fernández-Salguero (1) in a study on the influence of some factors on the coagulation time by vegetable rennet (Cynara sp.).
À medida que a concentração do extracto de cardo aumentava, o tempo de coagulação era menor. Numa concentração de $1 \%$, a coagulação foi realizada aos 18:75 minutos, enquanto que para uma concentração de 5\%, foram necessários apenas 3:255 minutos.

Em geral, altas concentrações de extracto de flor de cardo não influenciam significativamente a actividade de coagulação, no entanto, em baixas concentrações, o tempo de coagulação tende a aumentar com a diminuição da concentração de enzimas (Figura 1).

Estas observações estavam de acordo com as realizadas por Garcia et al. $(11,12)$ num estudo que comparou o uso de dois tipos de extracto de cardo (Cynara cardunculus L. e Cynara scolymus L.) no tempo de coagulação do leite. Resultado semelhante foi observado por Sanjuán e Fernández-Salguero (1) num estudo sobre a influência de alguns factores no tempo de coagulação pelo coalho de vegetais (Cynara sp.).

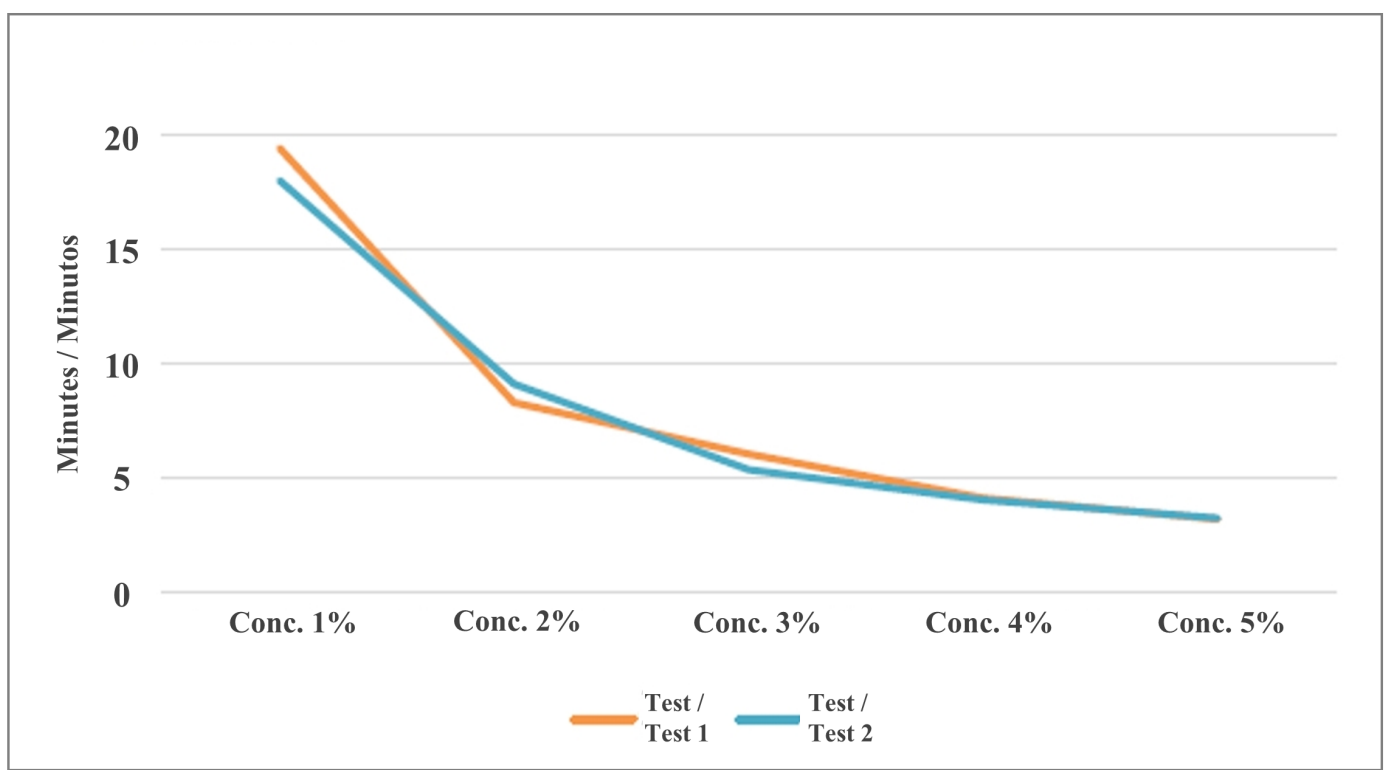

Figure 1 - Coagulation activity (minutes) of different concentrations of thistle in reconstituted milk Figura 1 - Actividade de coagulação (minutos) de diferentes concentrações de cardo no leite reconstituído 


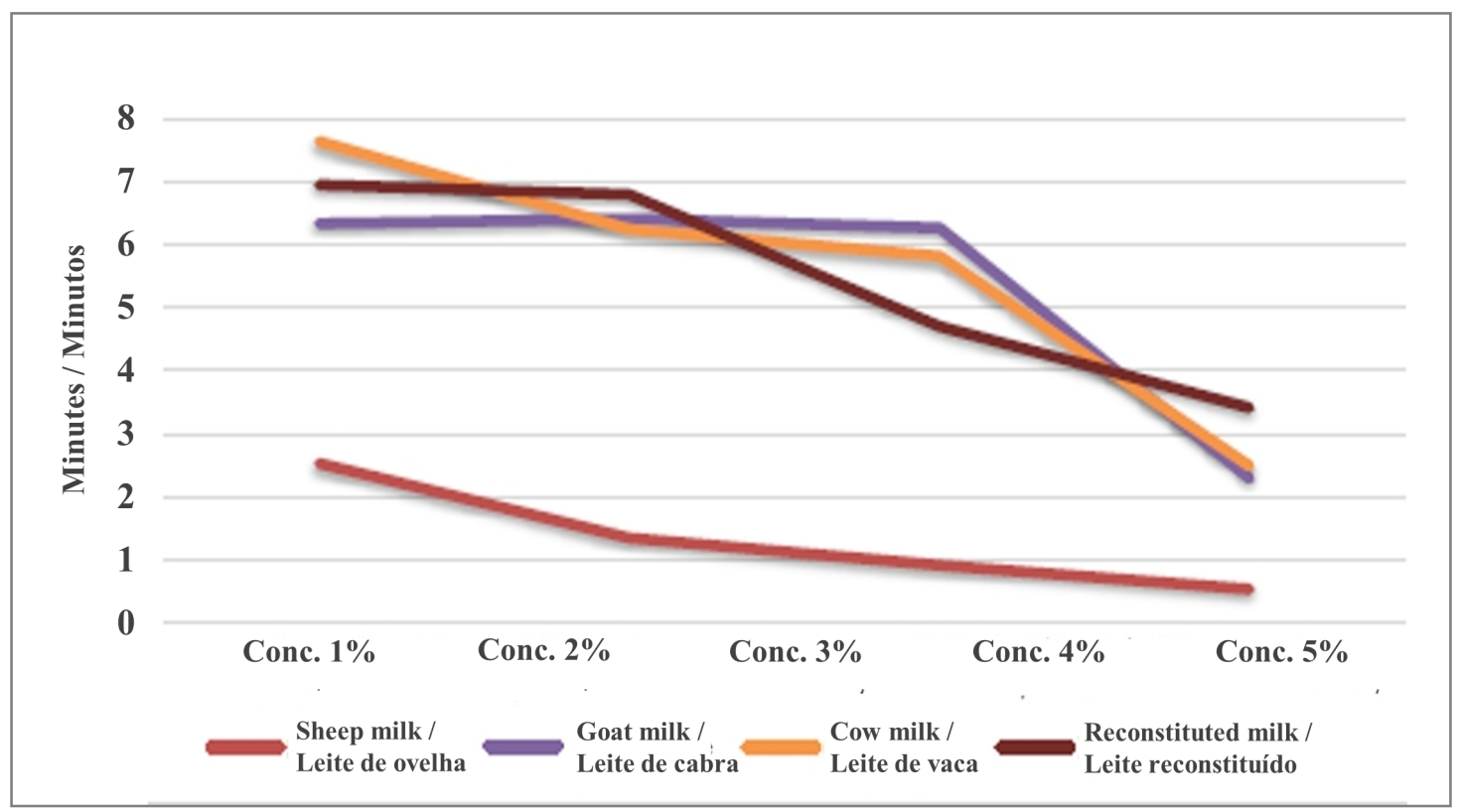

Figure 2 - Coagulation time (minutes) with different percentages (\%) of thistle extract in different types of milk

Figura 2 -Tempo de coagulação (minutos) com diferentes percentagens (\%) de extracto de cardo em diferentes tipos de leite

\section{Effect of the concentration of thistle extract on the time of milk coagulation}

The results of coagulation tests on different types of milk (sheep, cow, goat and reconstituted milk) carried out with different concentrations of thistle extracts are presented in Figure 2.

With regard to milk type, the sheep's milk took the least time to achieve coagulation with the different concentrations of thistle extract. As the concentration of the thistle extract used increased, coagulation time decreased.

A curious fact is that with goat's milk coagulation time remains at 6 minutes for concentrations of $2.3 \%$ and $4 \%$. It is possible that the protein composition of the milk of this species is not as sensitive to the concentration of the coagulation enzyme. Some authors (13) found goat milk with high fat content could be associated with better coagulation properties in cheese making, whereas milk with high protein content could be associated with delayed coagulation, and milk with a large quantity of casein associated with improved renneting ability only once coagulation had begun (i.e., curd firmness).

As already observed in the previous test for the test of rennet strength with reconstituted milk, it was observed that coagulation was slowest in the different milk types at the $2 \%$ concentration of thistle extract. In contrast,
Efeito da concentração de extracto de cardo no tempo de coagulação do leite

Os resultados dos testes de coagulação em diferentes tipos de leite (ovelha, vaca, cabra e leite reconstituído) realizados com diferentes concentrações de extractos de cardo são apresentados na Figura 2.

No que diz respeito ao tipo de leite, o leite de ovelha foi o que levou menos tempo para obter coagulação com as diferentes concentrações de extracto de cardo. À medida que a concentração do extracto de cardo usado aumentava, o tempo de coagulação diminuía.

Um facto curioso é que, com a coagulação do leite de cabra, o tempo permanece em 6 minutos para concentrações de $2,3 \%$ e $4 \%$. É possível que a composição proteica do leite desta espécie não seja tão sensível à concentração da enzima de coagulação. Alguns autores (13) descobriram que o leite de cabra com alto teor de gordura pode estar associado a melhores propriedades de coagulação na fabricação de queijos, enquanto o leite com alto teor de proteína pode estar associado a atraso na coagulação e o leite com uma grande quantidade de caseína associada apenas à melhoria da capacidade de coagulação. uma vez iniciada a coagulação (ou seja, firmeza da coalhada).

Como já observado no teste anterior para o teste à força do coalho com leite reconstituído, observou-se que a coagulação foi mais lenta nos diferentes tipos de leite na concentração de $2 \%$ de extracto de cardo. Por outro 
Table 3 - Coagulation times according to percentages of milk mixture of different species using $1 \%$ thistle extract. $\mathrm{X} \pm \mathrm{sd} \rightarrow$ average \pm standard deviation

Tabela 3 - Tempos de coagulação de acordo com percentagens da mistura de leite de diferentes espécies usando extracto de cardo a $1 \% . \mathrm{X} \pm \mathrm{sd} \rightarrow$ média \pm desvião padrão

\begin{tabular}{|c|c|c|c|c|c|c|c|c|}
\hline $\begin{array}{c}\text { \% Sheep Milk / } \\
\% \text { Leite de Ovelha }\end{array}$ & $\begin{array}{c}\text { \% Cow Milk / } \\
\% \text { Leite de Vaca }\end{array}$ & $\begin{array}{c}\text { \% Goat Milk / } \\
\% \text { Leite de Cabra }\end{array}$ & & $\begin{array}{l}\text { Coas } \\
\text { Temp }\end{array}$ & $\begin{array}{l}\text { Ilatio } \\
\text { de co }\end{array}$ & $\begin{array}{l}\text { Time } \\
\text { gulaç }\end{array}$ & & $X \pm s d$ \\
\hline 60 & 30 & 10 & 4.55 & 5.02 & 5.11 & 4.42 & 4.49 & $4.718 \pm 0.322$ \\
\hline 60 & 40 & $\mathbf{0}$ & 5.26 & 5.28 & 4.55 & 4.26 & 4.12 & $4.694 \pm 0.548$ \\
\hline 70 & 20 & 10 & 5.23 & 5.02 & 5.00 & 4.30 & 4.41 & $4.792 \pm 0.411$ \\
\hline 70 & 30 & $\mathbf{0}$ & 4.08 & 4.25 & 4.25 & 3.35 & 3.57 & $3.900 \pm 0.415$ \\
\hline 80 & 10 & 10 & 3.55 & 3.54 & 4.00 & 3.45 & 3.44 & $3.596 \pm 0.231$ \\
\hline 80 & 20 & $\mathbf{0}$ & 4.11 & 4.03 & 4.01 & 4.03 & 3.50 & $3.936 \pm 0.247$ \\
\hline 90 & $\mathbf{0}$ & 10 & 3.57 & 3.37 & 3.25 & 3.19 & 3.23 & $3.322 \pm 0.154$ \\
\hline 90 & 10 & $\mathbf{0}$ & 3.15 & 3.30 & 3.26 & 2.44 & 3.59 & $3.148 \pm 0.428$ \\
\hline 100 & 0 & $\mathbf{0}$ & 4.25 & 4.25 & 4.20 & 4.16 & 4.27 & $4.226 \pm 0.045$ \\
\hline
\end{tabular}

the $5 \%$ concentration of thistle extract was the fastest to achieve coagulation.

If we analyse the coagulation times individually according to the concentrations of thistle extract, we observe that in sheep's milk coagulation was achieved in less time. However, there are differences in the type of milk that were slower to coagulate as below:

- Concentration 2\%: Cow's milk and reconstituted milk were the slowest to coagulate.

- Concentration 3\%: Goat's and reconstituted milk were the slowest to coagulate.

- Concentration 4\%: Goat and cow milk were the slowest to coagulate.

- Concentration 5\%: Cow's milk and reconstituted milk were the slowest to coagulate.

To observe the influence of milk mixtures of different species on the remaining coagulation tests, a concentration of $1 \%$ was taken as a standard condition when preparing the thistle extract. This concentration resulted in a coagulation time approximately within the limits stipulated by the NOVO, Severinsen (9), or modified Berridge method, necessary for the Storch and Segelke equation to be valid (4.5 to 5.5 minutes).

\section{Influence of mixtures of milk used as a substrate on coagulation time}

Table 3 shows the descriptive results of the coagulation times obtained from the nine milk mixtures of different species using a thistle extract at $1 \%$, including the (milk) percentages covered by the DOP of Flor de Guía cheese. lado, a concentração de 5\% de extracto de cardo foi a mais rápida a obter coagulação.

Se analisarmos os tempos de coagulação individualmente de acordo com as concentrações de extracto de cardo, observamos que a coagulação do leite de ovelha foi alcançada em menos tempo. No entanto, existem diferenças no tipo de leite que foram mais lentas para coagular como abaixo se demonstra:

- Concentração 2\%: o leite de vaca e o leite reconstituído foram os mais lentos a coagular.

- Concentração de 3\%: o leite de cabra e o leite reconstituído foram os mais lentos a coagular.

- Concentração 4\%: o leite de cabra e vaca foi o mais lento a coagular.

- Concentração 5\%: o leite de vaca e o leite reconstituído foram os mais lentos a coagular.

Para observar a influência de misturas de leite de diferentes espécies nos restantes testes de coagulação, uma concentração de $1 \%$ foi tomada como condição padrão na preparação do extracto de cardo. Essa concentração resultou em um tempo de coagulação aproximadamente dentro dos limites estipulados pelo NOVO, Severinsen (9) ou método de Berridge modificado, necessário para que a equação de Storch e Segelke fosse válida (4,5 a 5,5 minutos).

Influência das misturas de leite utilizadas como substrato no tempo de coagulação

A Tabela 3 mostra os resultados descritivos dos tempos de coagulação obtidos das nove misturas de leite de diferentes espécies usando um extracto de cardo a $1 \%$, 
Based on the graphic exploration of these data, a linear model was proposed for the variable "coagulation time", depending on the percentage of sheep's milk used, with a correction for the concentration of $100 \%$ sheep's milk.

The selected model (best subset regression and BIC) has the form:

$$
\begin{gathered}
\text { Coagulation Time }= \\
\beta 0+\beta 1 . \% \text { Sheep }+\beta 2 \cdot(\% \text { Sheep }=100)+e
\end{gathered}
$$

being $I(\%$ Sheep $=100) 1$ or 0 according to $\%$ Sheep $=$ 100 or not and $e$ the error term.

The term $\beta 1$ reflects the expected change in coagulation times so that for each unit that increases the concentration of sheep's milk, the expected coagulation time decreases significantly by 0.05 minutes.

The goodness of the adjustment is given by the adjusted coefficient $\mathrm{R}^{2}$, which with $63.6 \%$ indicates that in this percentage the model explains the variability of the data (Figure 3).

As the concentration of sheep's milk increases (from 60 - 90\%), the clotting coagulation time decreases linearly. However, with $100 \%$ sheep's milk, coagulation time increases. The reason for this is unknown. The absence of milk of other species might explain a delay in the coagulation time.

The values observed for the coagulation times in the different mixtures vs. those predicted by the model is shown in Figure 4.

The prediction of the model was observed to be quite good, as the values predicted by the model have high concordance with those observed.

The data shows that there is an acceleration of coagulation by the vegetable thistle extract, as the percentage of sheep increases in the milk mixtures considered as acceptable by the DOP of Flor de Guía cheese.

Therefore, it can be assumed that the sensory characteristics of Flor de Guía cheese are affected by the percentages of sheep's milk that the producer intends to use as the raw material for his cheeses, as this will influence the speed of curd formation after the addition of thistle extract as a coagulant. Unfortunately, the samples from the different cheeses produced were not evaluated for sensory characteristics. This may be considered in a future study.

Ordiales et al. (14) observed that a high coagulant activity of the thistle extract after 24 hours of maceration improved the creaminess, viscosity and acceptability in Torta del Casar cheeses, such that the best thistles for the production of these cheeses would be those of greater coagulation activity. This seems to indicate that incluindo as percentagens (de leite) abrangidas pela DOP do queijo Flor de Guía.

Com base na exploração gráfica destes dados, foi proposto um modelo linear para a variável "tempo de coagulação", dependendo da percentagem de leite de ovelha utilizada, com correcção para a concentração de $100 \%$ de leite de ovelha.

O modelo selecionado (melhor regressão de subconjunto e BIC) tem a forma:

$$
\begin{gathered}
\text { Tempo de coagulação }= \\
\beta 0+\beta 1 . \% \text { Ovelha }+\beta 2 \cdot(\% \text { Ovelha }=100)+e
\end{gathered}
$$

sendo $I(\%$ Ovelha $=100) 1$ ou 0 de acordo com $\%$ Ovelha $=100$ ou não e $e$ o termo do erro.

O termo $\beta 1$ reflecte a mudança esperada nos tempos de coagulação, de modo que, para cada unidade que aumenta a concentração de leite de ovelha, o tempo esperado de coagulação diminui significativamente em 0,05 minutos.

A qualidade do ajuste é dada pelo coeficiente ajustado $\mathrm{R}^{2}$, que com $63,6 \%$ indica que nessa percentagem o modelo explica a variabilidade dos dados (Figura 3 ).

À medida que a concentração de leite de ovelha aumenta, o tempo de coagulação diminui linearmente com um efeito inexplicável que ocorre para $100 \%$ de leite de ovelha. A ausência de leite de outras espécies pode explicar um atraso no tempo de coagulação.

Os valores observados para os tempos de coagulação nas diferentes misturas vs. os previstos pelo modelo são mostrados na Figura 4.

A previsão do modelo foi observada como bastante boa, pois os valores previstos pelo modelo têm alta concordância com os observados.

Os dados mostram que existe uma aceleração da coagulação pelo extracto de cardo vegetal, pois a percentagem de ovelha aumenta nas misturas de leite consideradas aceitáveis pela DOP do queijo Flor de Guía.

Portanto, pode-se supor que as características sensoriais do queijo Flor de Guía sejam afectadas pelas percentagens de leite de ovelha que o produtor pretende usar como matéria-prima para os seus queijos, uma vez que isso influenciará a velocidade de formação de coalhada após a adição de extracto de cardo como coagulante. Infelizmente, as amostras dos diferentes queijos não foram avaliadas quanto às características sensoriais. Isso pode ser considerado num estudo futuro.

Ordiales et al. (14) observaram que uma alta actividade coagulante do extracto de cardo após 24 horas de maceração melhorou a cremosidade, a viscosidade e a aceitabilidade nos queijos Torta del Casar, de modo que os melhores cardos para a produção desses queijos 


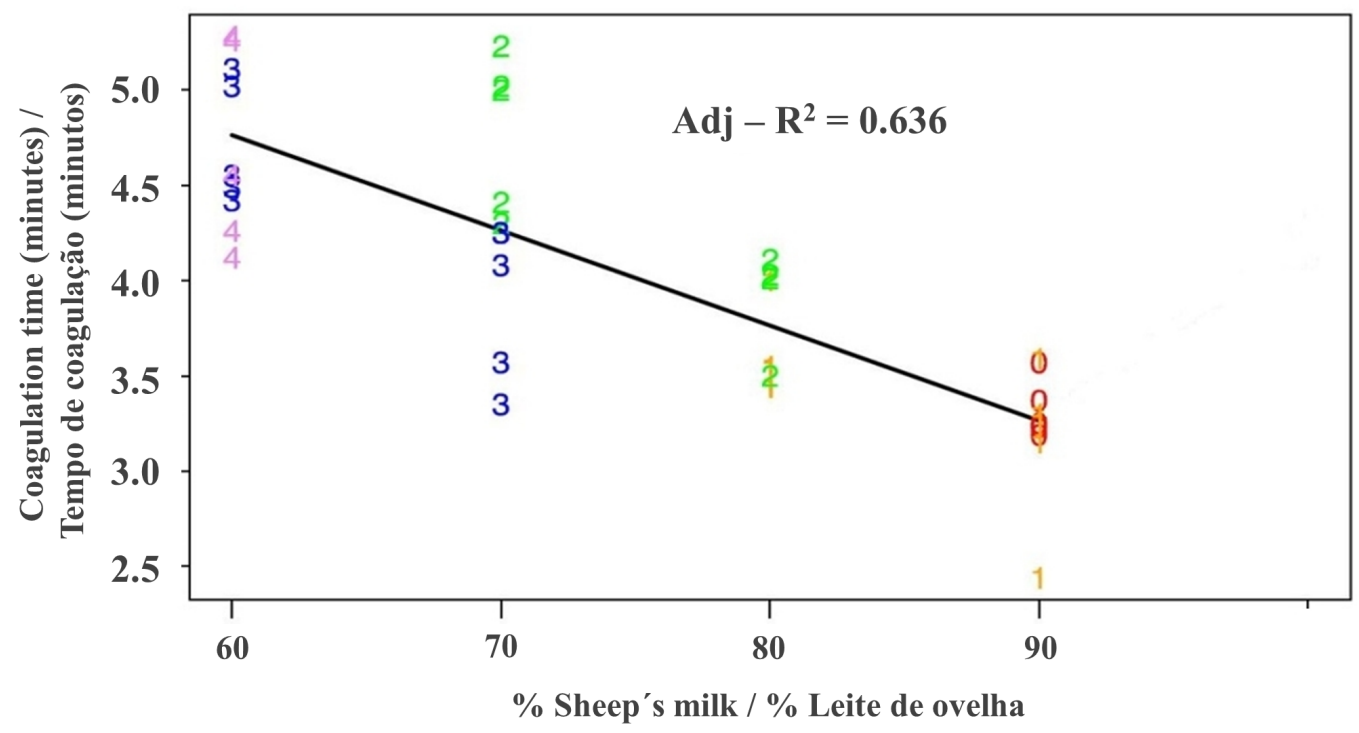

Figure 3 - Coagulation time versus \% of sheep milk. The lines correspond to the linear regression. Numbers (x 10) correspond to \% of sheep's milk. The goodness of fit is given by the adjusted R-Square (the model explains the $63.6 \%$ of the variability of data). As in Table 1 , the colored numbers refer to the percentage of sheep's milk in each mixture. Each color corresponds to a percentage of sheep's milk and the number that is repeated corresponds to one test.

Figura 3 - Tempo de coagulação versus \% de leite de ovelha. As linhas correspondem à regressão linear. Os números (x 10) correspondem a \% de leite de ovelha. A qualidade do ajuste é dada pelo R-Quadrado ajustado (o modelo explica os 63,6\% da variabilidade dos dados). À semelhança da Tabela 1, os números coloridos fazem referência à percentagem de leite de ovelha de cada mistura. Cada cor corresponde a uma percentagem de leite de ovelha e número que se repete corresponde a um ensaio.

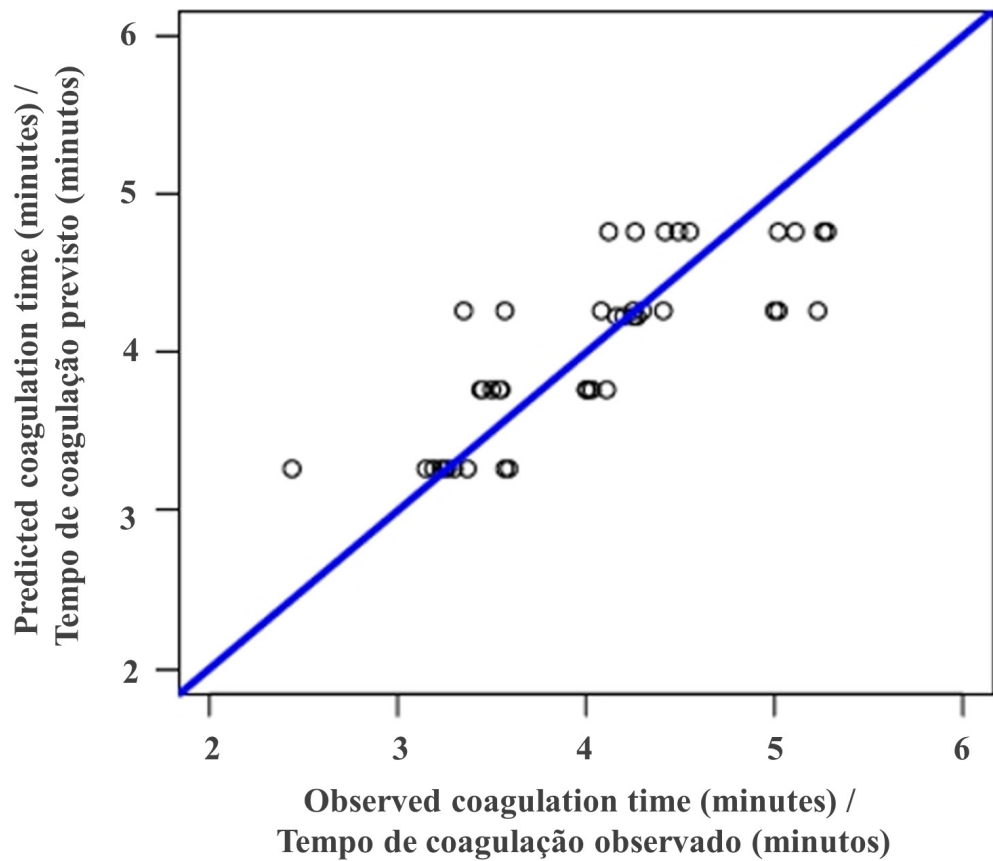

Figure 4 - Predicted coagulation time versus observed coagulation time. The line is the bisector of the first quadrant. The proximity of the points to the line indicates a good fit.

Figura 4 - Tempo de coagulação previsto versus tempo de coagulação observado. A linha é a bissetriz do primeiro quadrante. A proximidade dos pontos com a linha indica um bom ajuste. 
high percentages of sheep's milk used by cheesemakers in the production of Flor de Guía cheese might improve the organoleptic appreciation of these cheeses by consumers.

However, the same authors (14) indicated that most vegetable coagulants have a high proteolytic nature, and this excessive activity limits their use in cheese manufacturing, as it can lead to lower cheese yields, bitter tastes, acids, and texture defects. Therefore, in order not to over-accelerate the coagulation process in Flor de Guía cheeses, it would be advisable to use high percentages of sheep's milk, and to use thistle extracts with moderate strength. In this way, cheeses with pleasant sensory characteristics can be obtained, avoiding the appearance of devaluing defects.

There are several factors that related the kind of thistle flower with milk coagulation (or clotting) activity (MCA) due to great variability in the composition, mainly due to the degree of dryness of the thistle used. This dependence on previous drying of flower after harvesting (collection place, drying time, sun exposure, year, etc). Thus, traditional drying procedures seem to affect the flower MCA. In fact, the MCA was significantly lower for dried flower when compared with the non-dried flower (15). In both groups the results for MCA showed a wide variation and this can mean that uncontrolled utilization of thistle flower may be an unfavourable factor for a stable cheesemaking technology compared to the use of extracts.

The results obtained in this study also show that the exclusive use of sheep's milk delays the coagulation time of the thistle extract. This option, which is also available to cheesemakers assigned to this PDO, may be a good decision, since it would be "a way of accelerating the maturation of cheese made with sheep's milk, while preserving all the organoleptic properties of this type of cheese, adding different amounts of enzymes of C. cardunculus" (16). Nevertheless, further research studies could address other effects such as the influence of dry thistle, concentration, and the content of protein fractions and microorganisms, on milk composition, coagulation properties, and cheese-making. seriam aqueles com maior actividade de coagulação. Isso parece indicar que altas percentagens de leite de ovelha usado pelos queijeiros na produção do queijo Flor de Guía podem melhorar a apreciação organoléptica desses queijos pelos consumidores.

No entanto, os mesmos autores (14) indicaram que a maioria dos coagulantes vegetais têm uma alta natureza proteolítica, e essa actividade excessiva limita o seu uso na elaboração de queijos, pois pode levar a menores rendimentos, sabor amargo, ácidos e defeitos de textura. Portanto, para não acelerar o processo de coagulação nos queijos Flor de Guía, seria aconselhável usar altas percentagens de leite de ovelha e usar extractos de cardo com força moderada. Dessa forma, podem ser obtidos queijos com características sensoriais agradáveis, evitando o aparecimento de defeitos de desvalorização.

Existem vários factores que relacionam o tipo de flor de cardo com a actividade de coagulação do leite (ACL), devido à grande variabilidade na composição, principalmente devido ao grau de secagem do cardo utilizado. Isso depende da secagem prévia da flor após a colheita (local de colheita, tempo de secagem, exposição ao sol, ano, etc.). Assim, os procedimentos tradicionais de secagem parecem afectar a ACL da flor. De facto, a ACL foi significativamente menor para flores secas quando comparada com as flores não secas (15). Em ambos os grupos, os resultados da ACL mostraram uma grande variação e isso pode significar que a utilização descontrolada da flor de cardo pode ser um factor desfavorável para uma tecnologia estável de produção de queijo, comparado com a utilização de extractos.

Os resultados obtidos neste estudo também mostram que o uso exclusivo de leite de ovelha atrasa o tempo de coagulação do extracto de cardo. Essa opção, também disponível para os queijeiros designados para esta DOP, pode ser uma boa decisão, pois seria "uma maneira de acelerar a maturação do queijo produzido com leite de ovelha, preservando todas as propriedades organolépticas desse tipo de queijo, adição de diferentes quantidades de enzimas de C. cardunculus" (16). No entanto, outros estudos poderiam abordar a pesquisa sobre outros efeitos, como a influência do cardo seco, a concentração, o conteúdo das fracções proteicas e os microrganismos na composição do leite, nas propriedades da coagulação e na produção de queijo. 


\section{References / Referências}

1. Sanjuán, E. and Fernández- Salguero, J. (1994). Influencia de algunos factores sobre el tiempo de coagulacion por cuajo vegetal (Cynara sp.). ISSN 0212$1689, \mathrm{n} 13-6, \mathrm{p}$ 69-73.

2. Duarte. P, Figueiredo. R, Pereira. S and Pissarra. José. (2006). Canadian Jounral of Botany. Structural characterization of the stigma-style complex of Cynara cardunculus (Asteraceae) and immunolocalization of cardosins A and B during floral development. 84 (5), 737-749.

3. Sanjuán Velázquez. E and Fernández-Salguero, J. (1999). Influence of vegetable and animal rennet on proteolysis during ripening in ewes' milk cheese. Food Chemistry. 64 (2), 177-183.

4. Veríssimo P, Esteves C, Faro C and Pires E (1995). The vegetable rennet of Cynara cardunculus L. contains two proteinases with chymosin and pepsin-like specificities. Biotechnology Letters. 17 (6), 621-626.

5. Chazarra S, Sidrach L, López-Molina D and Rodríguez-López JN (2007). Characterization of the milk-clotting properties of extracts from artichoke (Cynara scolymus, L.) flowers. International Dairy Journal. 17 (12), 1393-1400.

6. Sampaio, P. N., Fortes, A. M., Cabral, J. M., Pais, M. S., \& Fonseca, L. P. (2008). Production and characterization of recombinant cyprosin B in Saccharomyces cerevisiae (W303-1A) strain. Journal of bioscience and bioengineering, 105(4), 305-312.

7. Coalho, PRODUCTOS ALIMENTARES, LDA. (2011). Ficha técnica de producto final. Queijo de Azeitão. Consultada el 19 de junio de 2019.https:/coalho. pt/wp-content/uploads/2018/04/ft-pf-01-queijo-de-Azeitão.pdf.

8. Official State Gazette (BOE) (2008). Resolución de 15 de abril de 2008, de la Dirección General de Industria Agroalimentaria y Alimentación, por la que se concede la protección nacional transitoria a la denominación de origen protegida «Queso Flor de Guía y Queso de Guía».

9. Severinsen, S.G., Norman, B.E., Nielsen, T., Wagner, J. (1979). Enzymatic treatment of whey permeate with recovery of enzyme by ultrafiltration, The World Galaxy for the World Dairy Industry, $\mathrm{n}^{\circ} 7$.

10. R Core Team (2016). R: A language and enviroment for statistical computing. R Foundation for Statistical Computing, Vienna, Austria. URL https://www.Rproject.org/.

11. García. V, Rovira. S, Teruel. R, Boutoial. K, Rodríguez. J, Roa. I and López. M.B. (2012). Effect of vegetable coagulant, microbial coagulant and calf rennet on physicochemical, proteolysis, sensory and texture profiles of fresh goat's cheese. Dairy Science \& Technology. 92 (6), 691-707.

12. García. V, Rovira. S, Boutoial. K and Álvarez. (2015). A comparison of the use of thistle (Cynara cardunculus L.) and artichoke (Cynara scolymus L.) aqueous extracts for milk coagulation. Dairy Science and Technology. 95 (2), 197-208.

13. Stocco, G., Pazzola, M., Dettori, M. L., Paschino, P., Bittante, G., \& Vacca, G. M. (2018). Effect of composition on coagulation, curd firming, and syneresis of goat milk. Journal of Dairy Science, 101(11), 9693-9702.

14. Ordiales. E, Benito. M․ J, Martín. A, Fernández. M, Hernández. A, Córdoba $\mathrm{M}^{\circ}$ de Guía. (2013). Proteolytic effect of Cynara cardunculus rennet for use in the elaboration of 'Torta del Casar' cheese. Journal of Dairy Research. 80 (4), 429-438.

15. Martins, A. L., de Vasconcelos, M. P., \& De Sousa, R. B. (1996). Thistle (Cynara cardunculus L) flower as a coagulant agent for cheesemaking. Short characterization. Le Lait, 76(5), 473-477.

16 Galán. E, Prados. F, Tejada. L and Fernández-Salguero. J. (2008). Influence of different amounts of vegetable coagulant from cardoon Cynara cardunculus and calf rennet on the proteolysis and sensory characteristics of cheeses made with sheep milk. International Dairy Journal. 18 (1), 93-98. 